\title{
Canadian Hydro-Electric Power Development during I930.
}

\section{By Dr. Brysson Cunningham.}

$\mathbf{T}$ HE remarkable progress which, during recent years, has characterised the development of natural sources of water power in Canada for the generation of electricity and other industrial uses continues at an unrelaxed pace, and the two annual reports ${ }^{1}$ recently issued by the Canadian Government contain a record of activities during 1930 which is quite up to the standard of preceding years. The present rate of development in round figures is 400,000 additional horse power a year, water power, as ascertained to Jan. 1 last, are set out in the table on p. 597. They may be instructively compared with the corresponding statistics at Jan. 1, 1930, which were published in Nature on May 31 last.

It will be noted that there has been no further revision of the total available horse power, which still stands at $33,617,500$ (ordinary six months' flow), although the report indicates that, in some of the more remote and less explored districts,

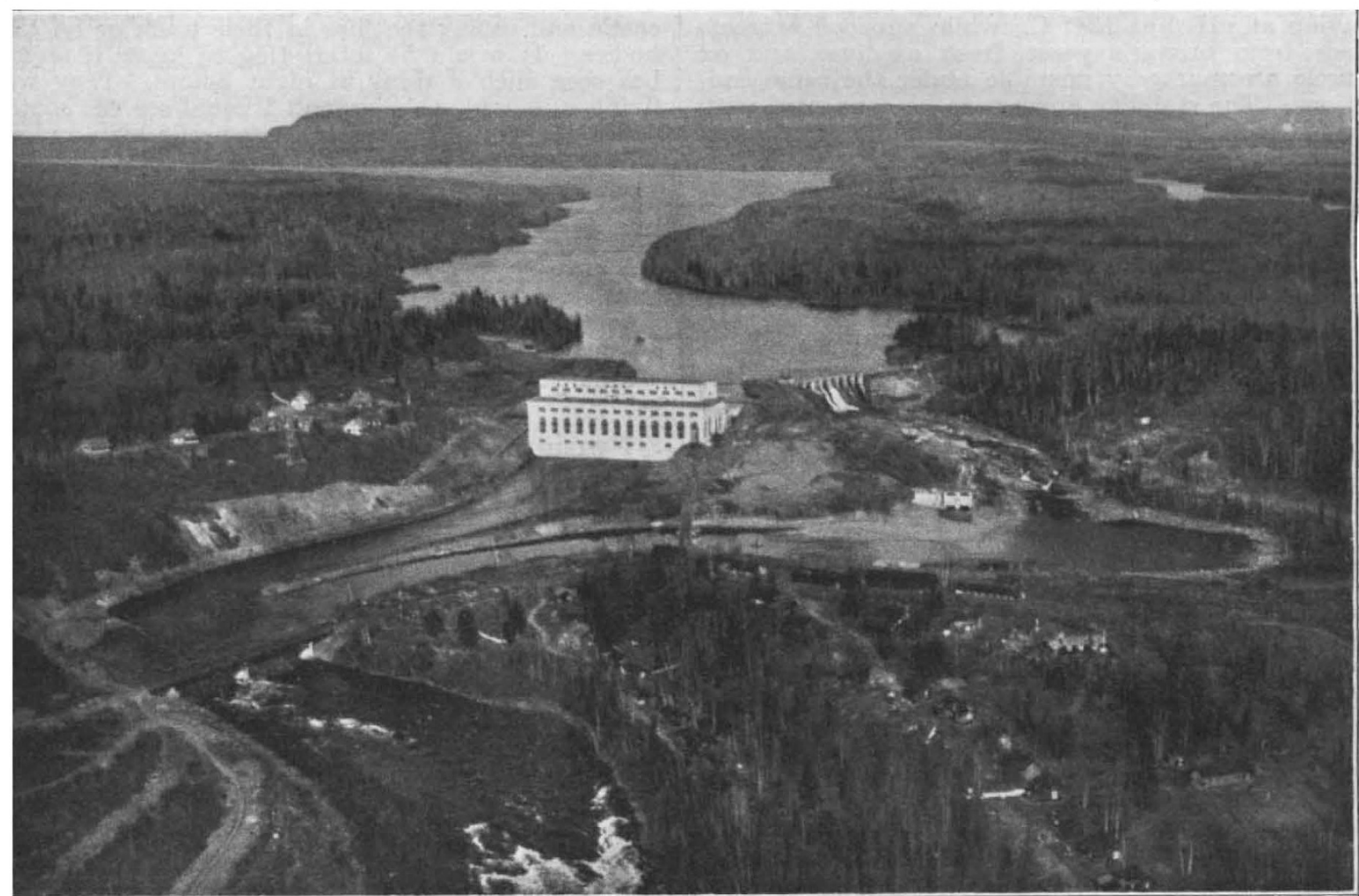

FIG. 1.-Cameron Falls development, Nipigon River, Ontario (75,000 horse power), of the Hydro-Electric Power Commission of Ontario. (By courtesy of the High Commissioner of Canada.)

and as the aggregate has grown from $3 \frac{1}{4}$ million horse power in January 1924 to a little more than 6 million horse power in January 1931, it is obvious that, roughly, the rate has now been maintained for a period of seven years. Taking the comparative value of coal fuel for power generating purposes at $5 \frac{1}{2}$ tons per annum per horse power (the most recent estimate), it can be inferred that Canada is progressively supplementing her extremely meagre resources in mineral fuel by the equivalent of a supply of about $2 \frac{1}{4}$ million tons of coal per annum. Moreover, as compared with coal, water power energy has the advantage of perpetuity, for, once installed, the turbines may continue to function for an indefinite period, in contradistinction to the inevitable, though gradual, exhaustion of fuel used in thermal stations.

The precise figures of available and developed the figures must be accepted as provisional and subject to expansion as the work of surveying and tabulation proceeds. Moreover, the present estimates are of a decidedly conservative character, as may be gauged from the fact that actual development of existing sites has produced power some 30 per cent in excess of the calculated maximum. Hence it is fairly safe to say that the total water horse power assets of Canada are of the order of 43 or 44 millions. According to information gathered from reports of the United States Geological Survey, this compares roughly with about 80 millions in the United States. The water power resources of Great Britain on this scale are insignificant: perhaps a million, or, at the outside, a million and a half.

As regards actually developed power, the aggregate increase throughout the Dominion is 397,850

No. 3207 , Vor. 127] 
horse power, of which the bulk has been realised in the provinces of Ontario and Quebec, though notable progress has also been made in British Columbia, Saskatchewan, and New Brunswick. Very little change has taken place in Nova Scotia, and the other four provinces remain stationary.

The province of Ontario heads the list of increments with 136,000 horse power. The most important item in this total is a tenth unit of 58,000 horse power added to the Queenston station at Niagara Falls, bringing the aggregate capacity of the station, which is the largest in Canada, up to the imposing figure of 560,000 horse power. Almost as large an increment is the recently completed 54,000 horse power development on the Nipigon River at Alexander Landing, a short dis- hand, in conjunction with the Ottawa Valley Power Company, the development of Chats Falls, on the Ottawa River, at a site which lies astride the Ontario-Quebec boundary, where, forming part of a project for 280,000 horse power, eight units, aggregating 224,000 , horse power, are being installed. Other important schemes have materialised at the Upper Notch station on the Montreal River, belonging to the Canada Northern Power Corporation; at the Canyon on the lower Abitibi River, under the Ontario Power Service Corporation, and at High Falls, Michipicoten River, for the Algoma District Power Company.

The Province of Quebec, with an increment of 122,700 horse power during the year, is a close second to Ontario. The additions have been con-

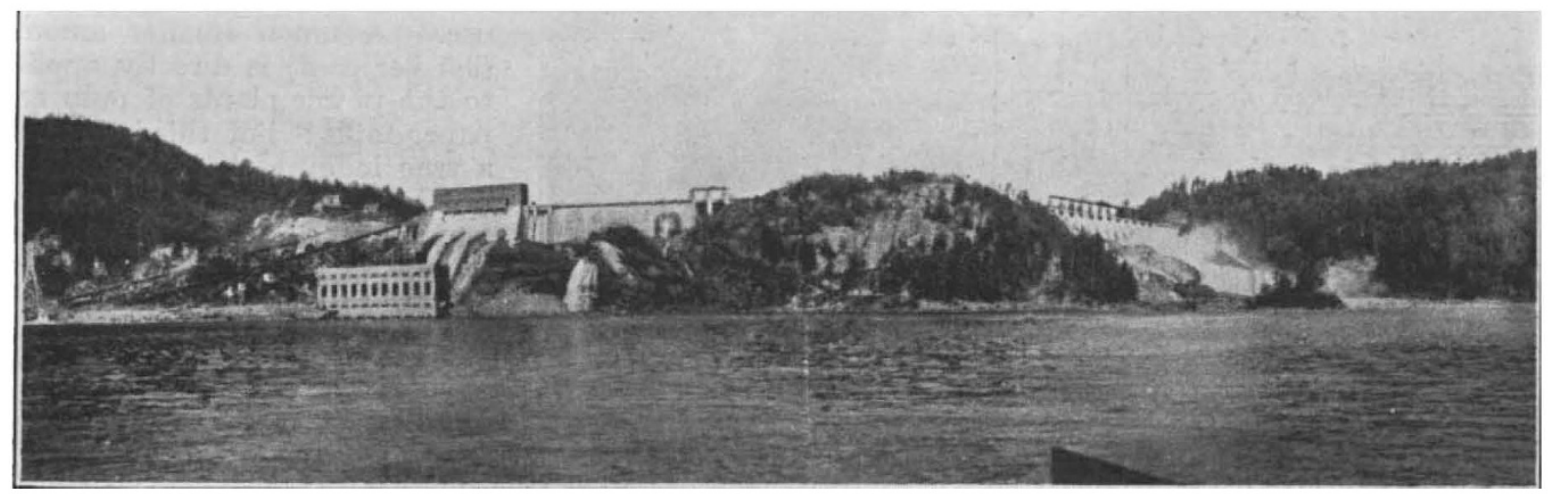

FIG. 2.-High Falls development, Lievre River, Quebec (90,000 horse power), of the MacLaren-Quebec Power Co. (By courtesy of the High Commissioner of Canada.)

tance below the 75,000 horse power installation at Cameron Falls (Fig. 1). The Hydro-Electric Power Commission of Ontario has at present in

Available and Devetoped Water Power in Canada JAN. 1, 1931.

\begin{tabular}{|c|c|c|c|}
\hline \multirow{2}{*}{ Province. } & \multicolumn{2}{|c|}{$\begin{array}{l}\text { Available } 24 \text {-hour Power at } \\
80 \text { per cent Efficiency. }\end{array}$} & \multirow{2}{*}{$\begin{array}{c}\text { Turbine } \\
\text { Installation. } \\
\text { (h.p.). }\end{array}$} \\
\hline & $\begin{array}{l}\text { At Ordinary } \\
\text { Minimum } \\
\text { Flow (h.p.). }\end{array}$ & $\begin{array}{l}\text { At Ordinary } \\
\text { Six Months' } \\
\text { Flow (h.p.). }\end{array}$ & \\
\hline British Columbia & $1,931,000$ & $5,103,500$ & 630,792 \\
\hline Alberta . & 390,000 & $1,049,500$ & 70,532 \\
\hline Saskatchewan & 542,000 & $1,082,000$ & 42,035 \\
\hline Manitoba & $3,309,000$ & $5,344,500$ & 311,925 \\
\hline Ontario . & $5,330,000$ & $6,940,000$ & $2,088,055$ \\
\hline Quebec . . . & $8,459,000$ & $13,064,000$ & $2,718,130$ \\
\hline New Brunswick & 68,600 & 169,100 & 133,681 \\
\hline Nova Scotia & 20,800 & 128,300 & 114,224 \\
\hline Prince Edward & & & \\
\hline 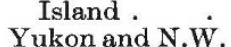 & 3,000 & 5,300 & 2,439 \\
\hline Territory & 294,000 & 731,000 & 13,199 \\
\hline Totals . & $20,347,400$ & $33,617,200$ & $6,125,012$ \\
\hline
\end{tabular}

Note.- "Ordinary Minimum Flow" is based on the averages of the flows for the lowest two periods of seven consecutive days in each year, over the period for which records are available. "Ordinary Six Months' Flow" is based on the continuous power indicated by the flow of the stream for six months in the year. The actual method to determine this flow is to arrange the months of each year according to the day of the lowest flow in each. The lowest of the six high months is taken as the basic month. The average flow of the lowest seven consecutive days in this month determines the ordinary six months' flow for that year. The average of such figures for all years flow used in the calculation.

No. 3207, VoL. 127] tributed by five organisations. The MacLarenQuebec Power Company has installed 90,000 horse power, out of a proposed 120,000 horse power development, on the Lievre River (Fig. 2), and contemplates the construction of a second 120,000 horse power station near the junction of that river with the River Ottawa. The Cedar Rapids Reservoir of 25 thousand million cubic feet capacity has also been brought into commission. The Shawinigan Water and Power Company has added a 25,000 horse power unit to the plant at Grand'mère and is now supplementing the station at La Gabelle with a 30,000 horse power unit, both on the St. Maurice River, farther up which an initial installation of 160,000 horse power is in hand at Rapide Blanc. Smaller installations have been effected by the Lower St. Lawrence Power Company and two other concerns.

The Province of Quebec will receive a considerable augmentation of power in the near future when the undertakings of the Beauharnois Power Corporation on the St. Lawrence River $(200,000$ horse power and ultimately 500,000 horse power), the Alcoa Power Company on the Saguenay River (260,000 horse power), and the joint development, above referred to, of the Ottawa Valley Power Company and the Hydro-Electric Power Commission of Ontario, on the Ottawa River, are com. pleted. The Saguenay River project at Chute-àCaron is actually at the point of completion. The 
Beauharnois project was referred to in NATURE of Dec. 14,1929, p. 930, at the time of the inauguration of constructional operations by His Excellency the Governor-General. It is a most important undertaking, comprising an overland canal from the St. Lawrence River, 15 miles in length, $600 \mathrm{ft}$. wide, and $27 \mathrm{ft}$. deep. The canal will extend from its intake at Lake St. Francis to a power house and locks at Beauharnois on Lake St. Louis, where a direct fall of $83 \mathrm{ft}$. will be obtained.

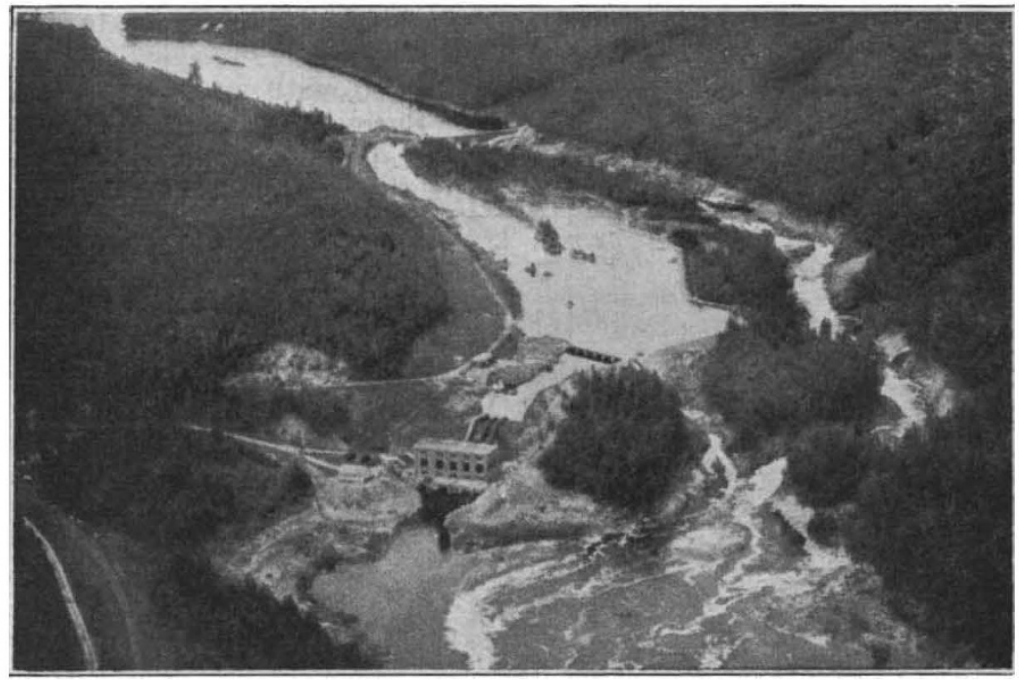

FIG. 3.-Aroostook Falls development, Aroostook River, New Brunswick (11,400 horse power), of the Maine and New Brunswick Electric Power Co., Ltd. (By courtesy of the High Commissioner of Canada.)

The financial commitments.in schemes of this magnitude are necessarily of a very high order. In the aggregate, it is computed that during the past year a sum of no less than 80 million dollars (say $£ 16,000,000$ ) has been expended on programmes of construction at the various centres, and it is estimated that a further outlay of 300 million dollars $(£ 60,000,000)$ will be incurred during the next two or three years. More than 11,000 men are at present employed in actual construc- tional work in situ, in addition to a large army of operatives engaged at factories and elsewhere in producing material and equipments.

There are many features of interest among the lesser undertakings, but space does not permit of reference to them. A picturesque view of a relatively minor development in New Brunswick is shown in Fig. 3.

A substantial part of the Report on the Water Power Resources of Canada is devoted to a detailed account of the various ways in which the developed power is utilised. The overwhelming bulk (85.1 per cent) is produced at central electric stations for general distribution for industrial, municipal, commercial, domestic, and agricultural use. A much smaller amount (9.5 per cent) is directly applied to the power plants of pulp and paper mills; but this is scarcely a true index of the demands of this industry, by far the most important in Canada, since large quantities of electricity are purchased en bloc from the central stations. The balance of $\mathbf{5 \cdot 4}$ per cent is absorbed in general industrial undertakings, such as mines and mineral reduction works, electro-chemical plants, saw and timber mills, machine shops, pumping plants, and for electric railway operation. The total water power installed at the present date works out at 617 horse power per 1000 of population, and places Canada in an outstanding position per capita among water-powerusing countries. The capital so far invested is estimated almost to reach the startling figure of $1,390,000,000$ dollars, or nearly $£ 280,000,000$.

1 Report No. 1462 : “Hydro-electric Progress in Canada in 1930 ” Report No. 1474: "Water Power Resources of Canada". (Ottawa Department of the Interior, Canada Dominion Water Power an Hydrometric Bureau.)

\section{Work of the Medical Research Council.}

\begin{abstract}
THE Report of the Medical Research Council 1 for 1929-30* indicates as usual the wide range of the researches carried out by members of its staff or by other investigators, assisted by grants. The value of the funds available has been enhanced by the collaboration of various public bodies with the Council in specific schemes of research and by the facilities provided for investigations by university and other laboratories. During the year, Sir Frederick Gowland Hopkins and Sir Charles Martin retired from the Council, and their places were filled by the appointment of Sir Charles Sherrington and Dr. J. A. Arkwright.
\end{abstract}

* Committee of the Privy Council for Medical Research. Report of the Medical Research Council for the year 1929-30. (London: H.M. Stationery Office, 1931.) Pp. 138. 2s. 6d. net.

No. 3207, VoL. 127]

\section{Clintcal Research and Experimental MEDiCINE.}

During the year, University College, London, established within its Hospital a Department of Clinical Research. Sir Thomas Lewis was appointed as the first physician in charge of the Department on his resignation as a member of the ordinary staff of the Hospital. He will continue, as before, to give whole-time service to the Medical Research Council. At Leeds, Birmingham, and Aberdeen, steps are being taken to provide full-time positions for clinical research. At Aberdeen also, the professor of pharmacology is to be given charge of beds within the new Royal Infirmary, thus reproducing the conditions at 